\title{
THE EXPLORATION OF TEACHERS' EFFICACY IN TEACHING: COMPARATIVE STUDY IN INDONESIA AND MALAYSIA
}

\author{
Muhammad Nur Wangid ${ }^{1 *}$, Ali Mustadi ${ }^{1}$, Siti Eshah binti Mokshien ${ }^{2}$ \\ ${ }^{1}$ Yogyakarta State University, Indonesia \\ ${ }^{2}$ Sultan Idris University of Education, Malaysia \\ *e-mail: m_nurwangid@uny.ac.id
}

\begin{abstract}
Teacher's self-efficacy can be varied according to experience gained, experience obtained from other people, social influences, and also physical and psychological welfare. In the context of teacher's efficacy in Indonesia and Malaysia, this psychological construct is likely to be different due to the different ways the teachers experienced it. The aim of the research is to examine the difference between teachers in Malaysia and Indonesia from the perspective of teacher's efficacy in teaching. This research is a comparative study. The subjects of this research were elementary school teachers who were continuing their studies in post graduate programs at Yogyakarta State University and Sultan Idris University of Education. They were given a scale of teacher efficacy in teaching consisting of three subscales, namely teacher's efficacy in involving students in learning, executing learning process, and class management. The findings showed that, in general, there were no significant differences in the teachers' efficacy in teaching between those in Malaysia and Indonesia. However, if the differences were seen from each factor, it appears that there were differences in the efficacy of teachers in involving students in learning, while the efficacy in instructional learning strategies, and efficacy in classroom management showed no significant differences.
\end{abstract}

\section{Keywords: teacher's self-efficacy in teaching, Indonesia-Malaysia}

\section{EKSPLORASI EFIKASI GURU DALAM MENGAJAR: STUDI KOMPARASI DI INDONESIA DAN MALAYSIA}

\begin{abstract}
Efikasi diri guru dapat berbeda-beda karena pengalaman yang diperoleh, pengalaman yang diperoleh dari orang lain, pengaruh sosial, serta kesejahteraan fisik dan psikologis. Dalam konteks efikasi guru Indonesia dan Malaysia tentu hal tersebut menjadikan berbeda karena berbeda dalam mengalaminya. Tujuan penelitian ini adalah mengungkap perbedaan yang ada antara guru Malaysia dan Indonesia dari perspektif efikasi guru dalam pembelajaran. Penelitian ini adalah penelitian komparatif. Subyek penelitian adalah guru-guru sekolah dasar yang sedang melanjutkan studi di program pascasarjana Universitas Negeri Yogyakarta dan Universiti Pendidikan Sultan Idris. Subyek diminta mengisi skala efikasi guru dalam pembelajaran yang terdiri dari tiga sub-skala yaitu efikasi guru dalam melibatkan siswa dalam belajar, melaksanakan strategi pembelajaran, dan menejemen kelas. Hasil penelitian menunjukkan bahwa secara umum dalam pembelajaran tidak terdapat perbedaan efikasi diri yang signifikan antara guru Indonesia dan Malaysia. Namun, secara faktor nampak ada perbedaan efikasi guru dalam melibatkan murid dalam pembelajaran, sedangkan efikasi dalam melaksanakan strategi pembelajaran, dan efikasi dalam manajemen kelas tetap tidak ada perbedaan yang signifikan.
\end{abstract}

\section{Kata Kunci: efikasi diri guru dalam pembelajaran, Indonesia and Malaysia}

\section{INTRODUCTION}

The teacher profession is a respected profession. Teachers in Malaysia and in Indonesia rank in the top five as revealed in the survey results "The Varkey Foundation Global Teacher Status Index 2018" (Dolton, Marcenaro, De Vries, \& She, 2018). In fact, teachers are one of the most valuable assets in a country's education system. That is because teachers are a very important component in schools, without teachers there is no school. One of the important things when talking about teachers is the issue of teacher competence. General understanding related to teacher competence, teachers must 
master three main areas, namely mastery competence in the field of study, pedagogical competence, and cultural competence (Selvi, 2010). Hence, teacher's competency means a teacher's ability to execute the tasks as the agent of learning, by having broad knowledge as well as authority in undergoing qualified teaching activity, thus, the goal of education can be reached. Therefore, a teacher in order to show their ability, they need to have the attitude, value and personality reflect their convincing ability.

Individual confidence in their ability plays an important role in their behavior. Goal realization obtained is usually based on their confidence about how the individual can behave to succeed. Individual assesses themselves according to their action (making a decision on a certain assignment, making or striving to solve assignment or when facing difficulties). Those play an important role in understanding belief in one's abilities (self-efficacy) (Septiana, 2018).

Self-efficacy becomes the attention of researchers in the last decades (Klassen, Tze, Betts, \& Gordon, 2011). Attention toward self-efficacy starts when Bandura introduces his concept (Gavora, 2010). Practitioners and researchers in various countries respond to it by conducting evaluation and research on self-efficacy about the condition of students and teachers. Researches on self-efficacy have lasted more than forty years (Zee \& Koomen, 2016). Especially in the Asia Pacific region, summarized in a book entitled Asia-Pacific Perspectives on Teacher Self-Efficacy (Garvis \& Pendergast, 2016). Nevertheless, comparison and development of teacher's self-efficacy from countries in the Asia Pacific region have not been found yet.

Teacher's self-efficacy is much useful and related to the learning process in class and students, as well as for the benefit of the teacher himself. Teacher's self-efficacy has been proven to have close relationships with many useful educational results such as; teacher perseverance, enthusiasm, commitment, and instructional behavior, even also related to student's results such as; achievement, motivation, and student efficacy (Tschannen-Moran \& Hoy, 2001). The explanation is also supported by other researches, that is the influence of teacher's efficacy toward perseverance of African-American teachers in suburbs (Milner \& Hoy, 2003), teacher's efficacy has an impact on teacher's enthusiasm seen in teacher's behavior who have high efficacy are not easily burnout - breaking enthusiasm (Skaalvik \& Skaalvik, 2010), teacher's efficacy is affected on teacher's commitment to work (Klassen \& Chiu, 2011), teacher's efficacy is affected on teacher's instructional behavior (Guo, Connor, Yang, Roehrig, \& Morrison, 2012) shows that the teacher's efficacy is manifested in teacher's support for student in learning and time for academic activity is getting better. As well as (Zee \& Koomen, 2016) explains that their research shows that teacher's self-efficacy has a positive relationship with student academic adjustment, teacher's behavior and practice pattern that is related with class quality, and factors in underlying teacher's psychological welfare, including personal achievement, work satisfaction, and commitment.

The teacher's self-efficacy is not only useful for the teacher himself, it also has impacts on student performance result such as; learning achievement and student efficacy level (Corkett, Hatt, \& Benevides, 2016) that explains there is a strong correlation between teacher's efficacy level and student efficacy level, that is also affected on learning achievement level which is getting better. Student efficacy also relates to student motivation (Akyol, 2016), from the research of data analysis shows that motivation level oriented in learning, lifelong learning tendencies and self-efficacy perception toward the high teaching profession of the teacher candidate. So that, the research has strategic function in education, the utilization of the research is not only for the teacher but also for student even school as an institution will also receive its benefit (Friedman \& Kass, 2002) class organization is getting better, learning climate is more open, and student academic adjustment, teacher's behavior, and practice pattern, and factors that underlying teacher's psychological welfare, including personal achievement, work satisfaction, and teacher commitment are better (Zee \& Koomen, 2016).

Self-efficacy is essentially the cognitive process resulting in the form of decision, belief, or appreciation about how far individual estimates his ability in executing assignment or certain action that is needed to reach the desired result (Bandura, 1997). Further explained that self-efficacy is not related to skill possessed, 
but related to individual confidence in what they can do with their skill no matter how big it is. Self-efficacy more prioritizes a component of self-belief that someone possessed in facing a situation that uncertain, unpredictable, and even full of pressure. Even though self-efficacy has a huge influence or cause-effect relation on individual action, self-efficacy combines with the environment, previous behavior, and another personal variable, especially hopes toward result in producing behavior. Self-efficacy will influence some aspects of one's behavior and cognition.

Someone with high self-efficacy will believe that they can do anything to change the situation in their surroundings, whereas someone with low self-efficacy regards themselves as basically cannot do anything for their surroundings. In a difficult situation, people with low efficacy tend to give up easily. Meanwhile, people with high self-efficacy will try harder to handle the challenges. This case has been shown in the research result proven that self-efficacy plays an important role in coping worker motivation to finish challenging workrelated with reaching certain goals (Ayupp \& Kong, 2010).

Thus in daily life, self-efficacy can be functioned to determine challenging desire and still survive in facing difficulties. There are a lot of researches shows that self-efficacy can be used to predict the working productivity of workers (Tierney \& Farmer, 2011) when problems emerge, strong self-efficacy of the worker encourages them to stay calm and find a solution instead of being confused and just pondering their inability. Effort and persistence produce achievements. From this perspective then teacher's self-efficacy has an important function to be able to give the best performance and result to the teacher. Research result on teacher's self-efficacy turn out to have a positive impact toward various teacher's practices in class, adjusting student academic performance with teacher's self-efficacy, and teacher's welfare, those are the result summarized from the research that has been conducted over twenty years (Zee \& Koomen, 2016). A teacher with good self-efficacy actually can decrease and prevent burnout in working (Skaalvik \& Skaalvik, 2010).

Teacher's self-efficacy refers to an individual (teacher) confidence in their abilities to undertake certain actions or assignments until success (Bandura, 1997). Self-efficacy determines how the teachers feel, think, motivate, and behave. Confidence produces various effects through four main processes. The four processes are cognitive, motivational, affective, and selection process. The cognitive process is a process involved in acquisition, organization, and information usage. The motivation process is an activating process to act, activation is started by generating psychical energy to act. With those intentions, there are some alternatives. Motivation level reflects in action program selected, and in intensity and effort perseverance. While the affective process is processed to manage emotional state and elicitation of emotional reaction (Bandura, 1994).

Perception toward self-efficacy of every individual develops from gradual achievements to certain abilities and skills continuously. Ability to perceive cognitively toward ability possessed elicits self-confidence and self-stability, that will be used as the foundation of individual to try as maximum as they can to achieve the fixed target (Bandura, 1997). The student's main task is to learn (target), therefore, by perceiving on ability possessed, it enables the teacher to estimate himself in involving a student in the learning process. A teacher's self-efficacy is a collection of various experience elements (practices) and development that has been accommodated and develops through an individual's observations toward a result or consequence of his action in various situations. Teacher's perception of self-ability is shaped since before and during becomes, teacher trough strengthening from people surround whether positive or negative. This element sooner or later is internalized so that is developed an understanding and belief about self-ability to undertake the learning process. Experience of being a student of teacher candidate, various education experience and training followed during becoming teacher, various fun and sad experiences during becoming teacher, several experience interaction with superior and co-teacher during at school (managing learning process), and so forth, those shape the teacher's self-efficacy. Therefore, teacher's self-efficacy covers teacher's selfefficacy to involve the student in the learning 
process (efficacy in instructional practices), and teacher's efficacy in managing calls (efficacy in classroom management) (Shaukat \& Iqbal, 2012).

Meanwhile, there are four things forming efficacy in a person (Bandura, 1997). The four things are experience gained (enactive mastery experience), experience obtained from other people (vicarious experience), social influence (verbal persuasion), also physical and affectivepsychological condition (physiological and affective states). In the context of a teacher's efficacy in Indonesia and Malaysia, it is certainly different in experiencing it. Experiences in getting the achievement, work performance scale demanded, and so forth are different between Indonesia and Malaysia (Artino, 2012; McLean, Eklund, Kilgus, \& Burns, 2018). A social environment with various conditions dealt with between Malaysia and Indonesia is different (Mehmood, 2019). Even though according to the 2018 status teacher index global survey teachers in Indonesia and Malaysia both have high esteem in society as a profession, also to the perception of Malaysian and Indonesian teachers the education system in the country already meets the standards, so does the teacher already has good competence (Dolton et al., 2018), does the teacher's self-efficacy differ?. Based on the theory explained above and various facts on possible differences occurred, the research aims to convey the differences between teachers in Indonesia and Malaysia from the perspective of teacher's self-efficacy in teaching.

\section{METHODS}

This explorative research uses a quantitative approach with comparative research types. Therefore this study compares one variable from two different subjects. The research is conducted by comparing elementary school teacher's efficacy between Indonesia and Malaysia in the learning process.

This is preliminary research that tries to uncover differences in teacher self-efficacy. Indonesian sample teachers of the research are elementary school teacher that is currently studying on the Post Graduate State University of Yogyakarta, so they are from various regions in Indonesia as much as 75 people. While samples from Malaysian teachers are teachers who are studying at Sultan Idris University of Education (UPSI) who come from various regions in Malaysia as much as 43 people. The total number of subjects is 118 people. Detailed sample characteristics can be seen in Table 1 .

An instrument used is Teachers' Sense of Efficacy Scale (TSES) (Tschannen-Moran \& Hoy, 2001) because the instrument is commonly used to measure teacher's efficacy in teaching (Tsigilis, Grammatikopoulos, \& Koustelios, 2007). The TSES instrument was translated according to need and expert validation was carried out. TSES instruments have been verified for validity and reliability and have met the theoretical model fit criteria in accordance with empirical data. TSES there are 24 items, each item with seven alternative ranges, consists of three subscales, which are teacher's efficacy to involve

Table 1. The Subjects' Characteristic

\begin{tabular}{|c|c|c|c|c|c|c|}
\hline \multirow{3}{*}{ Gender } & \multicolumn{4}{|c|}{ Elementary School Teacher's Nation } & \multirow{2}{*}{\multicolumn{2}{|c|}{ Total }} \\
\hline & \multicolumn{2}{|c|}{ Indonesia } & \multicolumn{2}{|c|}{ Malaysia } & & \\
\hline & $f$ & $\%$ & $f$ & $\%$ & $f$ & $\%$ \\
\hline Men & 27 & 36.0 & 6 & 14.0 & 33 & 28.0 \\
\hline Women & 48 & 64.0 & 37 & 86.0 & 85 & 72.0 \\
\hline Total & 75 & 100.0 & 43 & 100.0 & 118 & 100.0 \\
\hline \multicolumn{7}{|l|}{ Working Period } \\
\hline $1-5$ Year & 26 & 34.7 & 14 & 32.6 & 40 & 33.9 \\
\hline $6-10$ Year & 26 & 34.7 & 14 & 32.6 & 40 & 33.9 \\
\hline $11-15$ Year & 7 & 9.3 & 11 & 25.6 & 18 & 15.3 \\
\hline $16-20$ Year & 2 & 2.7 & 2 & 4.7 & 4 & 3.4 \\
\hline$>20$ Year & 14 & 18.7 & 2 & 4.7 & 16 & 13.6 \\
\hline Total & 75 & 100.0 & 43 & 100.0 & 118 & 100.0 \\
\hline
\end{tabular}


the student in the learning process (efficacy in student engagement) consist of 8 items, teacher's efficacy in executing learning process (efficacy in instructional practices) consist of 8 items, and teacher's efficacy in managing class (efficacy in classroom management) there are 8 items.

To find out whether there are differences in teacher's self-efficacy in learning, it is used $t$-test analysis technique (independent $t$-test). Analysis is carried out sequentially starting from a combination of all aspects to see differences in the teacher's self-efficacy in learning, and continued with an analysis of each aspect to see the differences in each aspect of teacher's selfefficacy in learning, namely efficacy for student involvement, efficacy for learning strategies, efficacy for classroom management. And even analysis of differences on each scale item.

\section{FINDINGS AND DISCUSSION Findings}

Before analyzing the differences with the $t$-test, a descriptive analysis was carried out with the results in Table 2.
Based result from descriptive analysis there are no extreme differences so this condition is increasingly encouraging to reveal how variations and dynamics of self-efficacy in teaching exist in Indonesian and Malaysian teachers. Difference analysis is carried out starting from the total of each country, and followed by analysis of differences from each sub-scale, even analysis each item.

First of all, it is conducted a test on the differences in the efficacy between teachers in Indonesia and Malaysia. Different-test analysis in this section is used $t$-test (independent $t$-test), which is to determine the differences between teacher's efficacy in Indonesia and Malaysia. The result of the different analyses is presented on Table 3.

Based on the calculation as mentioned in the Table 3, it is obtained $t_{\text {-count }}$ result for teacher's efficacy as much as 1.917 with $p=$ .058 ; it turns out that $\mathrm{p}$ or significant is more than determined, which is $5 \%(p>.05)$; thus the $t_{- \text {count }}$ is not significant, which means there are no significant differences in teachers' efficacy

Table 2. Statistic Descriptive of Differences in Teacher's Self-Efficacy in Learning

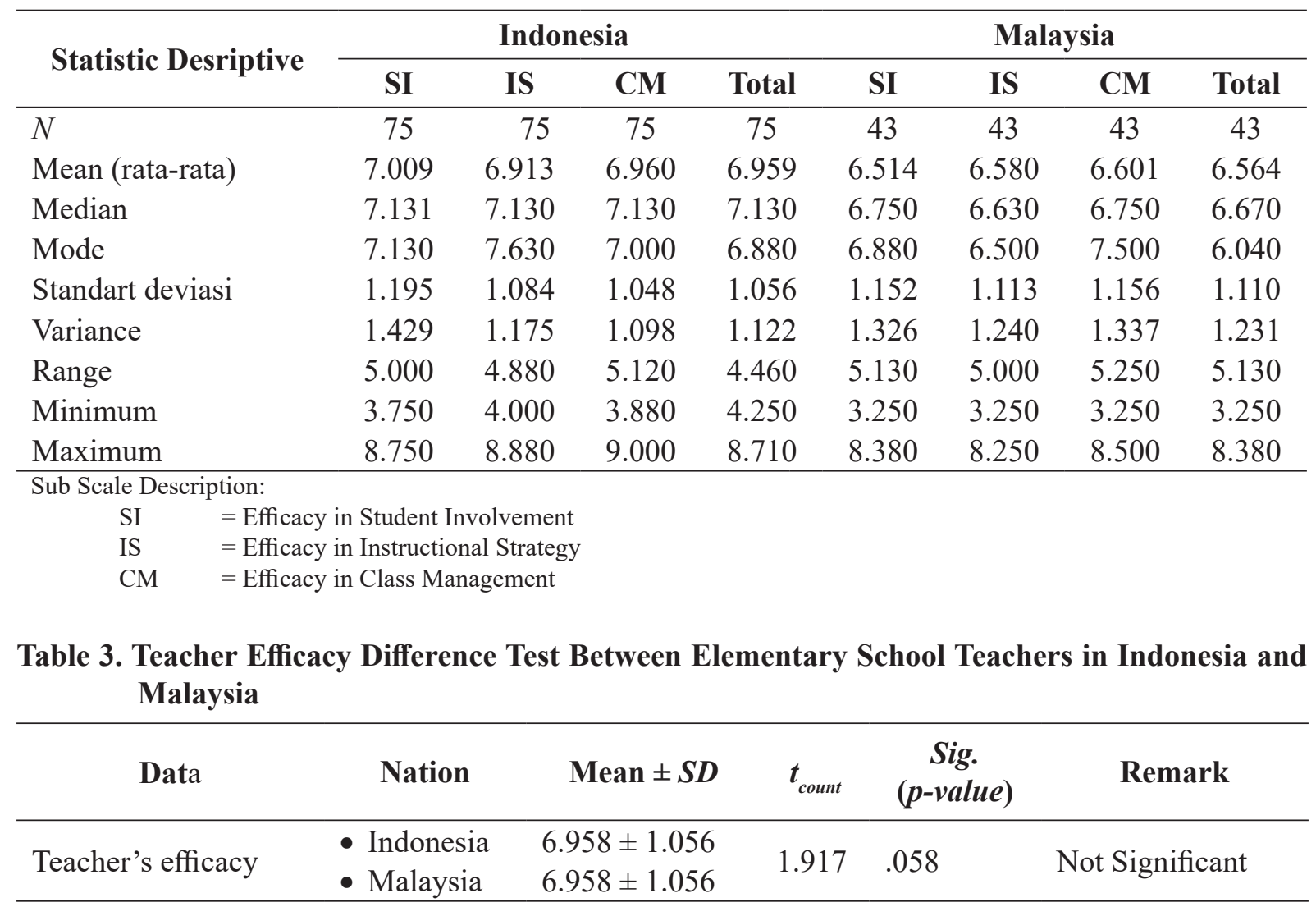


between elementary school teachers in Indonesia and Malaysia.

The next analysis is about the differences in each subscale and continued analysis of the differences in each scale item, the results of the analysis are presented as follows.

\section{Teacher's Efficacy in Student Involvement}

From descriptive statistics it can be understood that mean of Indonesian teachers 7.009 and Malaysian teachers 6.514, standard deviation Indonesian teachers 1.195 and Malaysian teacher 1.152. The calculation result proves that from three sub-scales to measure elementary school teachers' efficacy; there is one sub-scale with significantly different $(p<.05)$ between elementary school teachers in Indonesia and Malaysia, which is the sub-scale of teachers' efficacy in student involvement (.030). The difference in mean scores subscale on the efficacy of student involvement is significant. Indonesian teachers is better than Malaysian teachers in efficacy student involvement.

Next, the analysis continues with analysis of the different tests on each item of the teacher efficacy subscale in student involvement, is summarized in the Table 4.

The Table 4 shows that from the 8 questions in measuring teacher's efficacy in student involvement, there are three questions items that are different significantly $(p<.05)$ between elementary school teachers in Indonesia and Malaysia, those are items number: 1 . How much can you do to handle the most difficult student?; 2. How much can you do to help your students to think critically?; and 22. How much can you do to help the family in handling their children to behave well in school?

\section{Teacher's Efficacy in Instructional Strategy}

Results of the second sub-scale analysis follows, unlike the first aspect, aspect teacher's efficacy in instructional strategy (.116) is not significantly different $(p>.05)$ between elementary school teachers in Indonesia and Malaysia. This reality can be understood from descriptive statistics including the average (mean) efficacy of instructional strategies (Indonesian teachers 6.913 while Malaysian teachers 6.581) and standard deviations (Indonesian teachers 1.084 while Malaysian teachers 1.113). The analysis continues with testing the differences in each item subscale of the teacher efficacy in instructional strategies, summarized in the Table 5.

Based on analysis result presented on the Table 5, it is found that from 8 items to measure teacher's efficacy in instructional strategy, there is only one significantly different statement item $(p<.05)$ between elementary school teachers in Indonesia and Malaysia, that is item number 20, which is: "how far can you give explanation or alternative example when students are confused?"

Table 4. Different Test on Every Item on Teacher's Efficacy in Student Involvement Sub Scale in Elementary School Teachers in Indonesia and Malaysia

\begin{tabular}{|c|c|c|c|c|}
\hline No. & $\begin{array}{l}\text { No. } \\
\text { Item }\end{array}$ & Question & $t_{\text {-count }}$ & p-Value \\
\hline 1. & 1 & How much can you do to handle the most difficult student? & 2.487 & $\left..014^{*}\right)$ \\
\hline 2. & 2 & How much can you do to help your students to think critically? & 2.023 & $\left..045^{*}\right)$ \\
\hline 3. & 4 & $\begin{array}{l}\text { How much can you do to encourage a student that shows less } \\
\text { interest in a school assignment? }\end{array}$ & .947 & .345 \\
\hline 4. & 6 & $\begin{array}{l}\text { How much can you can to ask the student to believe that they } \\
\text { can do better in the school assignment? }\end{array}$ & 1.825 & .071 \\
\hline 5. & 9 & How much can you do to help the student to asses learning? & 1.319 & .190 \\
\hline 6. & 12 & How much can you do to maintain student creativity? & 1.496 & .138 \\
\hline 7. & 14 & $\begin{array}{l}\text { How much can you do to enhance a student's understanding of } \\
\text { an unsuccessful student? }\end{array}$ & 1.271 & .206 \\
\hline 8. & 22 & $\begin{array}{l}\text { How much can you do to help the family in handling their } \\
\text { children to behave well in school? }\end{array}$ & 2.309 & $\left..023^{*}\right)$ \\
\hline
\end{tabular}


Table 5. Different Test on Every Item of Teachers' Efficacy Sub-Scale in Instructional Strategy between Elementary School Teachers in Indonesia and Malaysia

\begin{tabular}{|c|c|c|c|c|}
\hline No. & $\begin{array}{l}\text { No. } \\
\text { Item }\end{array}$ & Question & $t_{\text {-count }}$ & p-Value \\
\hline 1. & 7 & $\begin{array}{l}\text { How good can you respond to difficult questions from the } \\
\text { student? }\end{array}$ & .947 & .345 \\
\hline 2. & 10 & $\begin{array}{l}\text { How much can you measure students' understanding of what } \\
\text { you have worked on? }\end{array}$ & .945 & .347 \\
\hline 3. & 11 & How far can you make good questions for your students? & .743 & .459 \\
\hline 4. & 17 & $\begin{array}{l}\text { How much can you work to adjust lessons with descent individual } \\
\text { student levels? }\end{array}$ & 1.121 & .265 \\
\hline 5. & 18 & How much can you use various assessment strategies? & 1.612 & .110 \\
\hline 6. & 20 & $\begin{array}{l}\text { How far can you give an explanation or alternative example } \\
\text { when the students are confused? }\end{array}$ & 2.554 & $\left..012^{*}\right)$ \\
\hline 7. & 23 & How much can you execute an alternative strategy in your class? & .129 & .897 \\
\hline 8. & 24 & $\begin{array}{l}\text { How much can you provide appropriate challenges to excellent } \\
\text { students? }\end{array}$ & 1.428 & .156 \\
\hline
\end{tabular}

\section{Teacher's Efficacy in Class Management}

Descriptive statistical calculation results about the average score of teacher's efficacy in class management for Indonesian teachers 6.960 whereas Malaysian teachers 6.601, and the standard deviation of Indonesian teachers 1.048 and Malaysian teachers 1.156. As with the second sub-scale, sub-scale teacher's efficacy in class management (.087) is not significantly different $(p>.05)$ between elementary school teachers in Indonesia and Malaysia. To further understand further analysis is carried out on testing the differences of each item from the subscales teachers' efficacy in class management, as presented in Table 6 .

From the sum up analysis above, it is found that from 8 questions to measure teacher's efficacy in class management, there are two question items with significantly different $(p$ $<.05$ ) between elementary school teachers in Indonesia and Malaysia, which are items number 19 and 21. The questions are: "How much can you do to avoid some troubling students from learning failure?" and "How much can you respond toward the student who violates?"

\section{Discussion}

From the main analysis result, it is derived that $t_{\text {-count }}$ for teacher's efficacy is as much as 1.917 with $p=.058$; it turns out that $\mathrm{p}$ or significance is more than expected, which is
$5 \%(p>.05)$; so that, the $t_{\text {-count }}$ is not significant; which means that there is no significant difference on teacher's efficacy between elementary school teachers in Indonesia and Malaysia. The condition of social development in Malaysia and Indonesia is relatively the same. Beginning with the condition of the colonized country then possessed its independence and develop into a sovereign nation, and also try to develop the country independently. That condition underly society's communal awareness attached to each individual. Malaysia once has imported teachers and lecturers from Indonesia. The condition more or less gives an impact on education in Malaysia. Hence, education culture that developed in Indonesia and Malaysia is also relatively the same. This case makes the teacher's condition in Malaysia and Indonesia is same in its educational behavior (Rido \& Sari, 2018).

Besides that, as mentioned in the theory, there are four sources of changes in self-efficacy (Bandura, 1997). Research on Malaysian teachers shows that there are three dominant self-efficacy sources, which are: lesson mastery experience (mastery experience), the existence of example or role model that can be made as learning material (vicarious experience), and persuasions from social environment (social persuasion) (Chin, Roslan, Kadir, \& Mahyuddin, 2013). Likewise in Indonesia, the teacher's experience affects the ability of the teacher to 
Table 6. Different Test of Every Item on Teacher's Efficacy Sub Scale in Class Management between Elementary School Teachers in Indonesia and Malaysia

\begin{tabular}{|c|c|c|c|c|}
\hline No. & $\begin{array}{l}\text { No. } \\
\text { Item }\end{array}$ & Question & $t_{\text {-count }}$ & p-Value \\
\hline 1. & 3 & $\begin{array}{l}\text { How much can you do to control disturbing behavior in the } \\
\text { class? }\end{array}$ & .688 & .493 \\
\hline 2. & 5 & $\begin{array}{l}\text { How far can you make your hope becomes clear on student } \\
\text { behavior? }\end{array}$ & 1.692 & .093 \\
\hline 3. & 8 & $\begin{array}{l}\text { How well can you create a routine to maintain activity still run } \\
\text { smoothly? }\end{array}$ & 1.036 & .302 \\
\hline 4. & 13 & $\begin{array}{l}\text { How much can you do to ask your students to obey classroom } \\
\text { regulations? }\end{array}$ & 1.229 & .222 \\
\hline 5. & 15 & $\begin{array}{l}\text { How much can you do to calm down the student who is } \\
\text { disturbing or noisy? }\end{array}$ & 1.297 & .197 \\
\hline 6. & 16 & $\begin{array}{l}\text { How good can you create a class management system with each } \\
\text { different student group? }\end{array}$ & .920 & .360 \\
\hline 7. & 19 & $\begin{array}{l}\text { How much can you do to avoid some troubling students from } \\
\text { learning failure? }\end{array}$ & 2.550 & $.012^{*}$ \\
\hline 8. & 21 & How much can you respond to the student who violates? & 2.271 & $\left..025^{*}\right)$ \\
\hline
\end{tabular}

involve students in learning (Pardimin, 2018), teacher's self-efficacy in developing curriculum relates to teacher's self-efficacy in teaching (Susilana, Asra, \& Herlina, 2014), after attending collaborative lectures (experiencing social persuasion) the teacher's self-efficacy changes for the better (Pujaningsih \& Ambarwati, 2020).

Generally, teacher's self-efficacy in teaching is not much difference between teachers in Indonesia and Malaysia, however, if it is seen from the three subscales in measuring self-efficacy of elementary school teachers, there is one subscale with significantly different $(p<.05)$ between elementary school teachers in Indonesia and Malaysia, which are teacher's efficacy subscale in student involvement. The average teacher's efficacy in teaching Indonesia is higher than that of Malaysian teachers. This is possible because Indonesian teachers consider the ability to involve students in learning is very important (Jayanti \& Wahyudin, 2019), teacher's pedagogical competence correlates with the implementation of teacher learning (Setiawan \& Dewi, 2019). While the teacher's efficacy in instructional strategy and teacher's efficacy in class management is not significantly different $(p>.05)$ between elementary school teachers in Indonesia and elementary school teachers in Malaysia.
This is because Malaysian teachers are seen more assiduously and focus on the students' learning process. Survey result on "Global Education Census Report" that surveys, one of them are the things teachers do in class, is reported that Malaysian teachers still conduct the learning process diligently although the lesson is disliked by the students (Cambridge Assessment International Education, 2018). Research conducted on students of history teachers candidate shows a teacher's ability to involve the student in teaching a history lesson, it is reported that Malaysian teachers are better than Indonesian (Awang, Ahmad, Yakub, \& Seman, 2016).

Analysis result from the first aspect shows that from 8 questions to measure teacher's selfefficacy in student involvement, there are three questions items with significantly different $(p$ $<.05$ ) between elementary school teachers in Indonesia and Malaysia, which are item number 1: "How much can you do to handle the most difficult student?; number 2: "How much can you do to help your student think critically?; and number 22: "How much can you do to help a family in handling their children to behave well in the class?". All three questions show a teacher's involvement to help a student who has difficulties, develop the ability to think critically 
and help a family in order the student can behave well in school. The willingness of Malaysian teachers, to be involved in helping students who have difficulties and develop the ability to think critically, has been submitted in other research, reported that teacher's efficacy in student involvement - emerged as the best predictor in student achievement for English literacy (Lih \& bin Ismail, 2019). While willingness to help a student to behave well in the school is suitable for another research finding that defines teacher's self-efficacy refers to teacher's belief that their effort can increase morale and student behavior (Rahimah, Abu, Ismail, \& Mat Rashid, 2014).

While from the second aspect it is found that from the 8 questions in measuring teacher efficacy in instructional strategy, there is one significantly different question item $(p<.05)$ between Elementary School teacher in Indonesia with Elementary School teacher in Malaysia, which is item number 20, that is: "How far can you give explanation or alternative example when the student is confused?" related to instructional strategy where Indonesian teachers have higher self-efficacy than Malaysian teachers, especially in explaining, for confused students, can be described as follows. The research sample is teachers who live in Yogyakarta Special Region that had experienced an earthquake disaster. Experience in disaster brought better awareness and patient to help students. Research shows that there is a significant relation between pressure experienced by the teacher after trauma and the general belief of the teachers about their selfefficacy (Seyle, Widyatmoko, \& Silver, 2013). It means when there is a student who has not mastered the lesson yet even in a depressed condition and confused, the teacher still can execute his teaching strategy as well as possible, by giving an explanation or example. The large number of training on learning strategies implemented, especially when curriculum changes take place, will make Indonesian teachers better self-efficacy in implementing learning strategies (Moma, 2014).

From the third analysis aspect, it is found that from the 8 questions to measure teacher's self-efficacy in class management, two question items are significantly different $(p<.05)$ between Elementary School teachers in Indonesia with Elementary School teachers in Malaysia, which are item number 19 and 21.
The question is number 19, "How much can you avoid some troubling student from learning failure?", and number 21, "How much can you respond toward the student who violates?". Self-efficacy of Malaysian teachers in avoiding some troubling students from learning failure is better than Indonesia teachers, and responding to a student who violates, that is better than Indonesian teacher, can be derived from Global Census Report 2018, it is stated that Malaysia is the top country in handling learning failure and admitting student academic achievement. It is reported that $45 \%$ of the teachers make a special meeting to acknowledge student achievement and $48 \%$ said that they give rewards to the students. This fact is the highest one globally (Cambridge Assessment International Education, 2018).

\section{CONCLUSION}

Based on the research result and discussion described above, it can be concluded that the teacher's self-efficacy in teaching between teachers in Indonesia and Malaysia generally has no significant difference. Nevertheless, if it is seen from the existing subscale, self-efficacy of Indonesian and Malaysian teachers is different in self-efficacy to involve students in learning. So does, if it is seen in question item submitted, so, mostly it is not much significantly different, the differences appear in some aspects which mostly show the efficacy of Malaysian teachers is higher than Indonesian. This condition brought the implication that teacher's selfefficacy in Indonesia in the teaching context needs to be improved through some aspects. First, experience gained (enactive mastery experience), which means the teachers are allowed to excel and feel successful. Second, the teacher can have an experience that is obtained from other people (vicarious experience), it means there are an example and an obvious role model on how the assignment must be conducted correctly. Third, the existence of social influence (verbal persuasion), which means teachers must have social groups that can strengthen their belief that they can perform the assignment excellently. Four, teacher's condition must be good in physically and affective-psychologically (physiological and affective states), it means that becoming teacher must be guaranteed on both physically (secure and comfortable in working) and psychological welfare (free from pressure so 
they can work, expressing their ability). Those things are the responsibilities of those who care about education in Indonesian.

\section{REFERENCES}

Akyol, B. (2016). Teacher self-efficacy perceptions, learning oriented motivation, lifelong learning tendencies of candidate teachers: A modeling study. Egitim Arastirmalari - Eurasian Journal of Educational Research, 16(65), 19-34. doi:10.14689/ejer.2016.65.02.

Artino, A. R. (2012). Academic self-efficacy: from educational theory to instructional practice. Perspectives on Medical Education, 1(2), 76-85. doi:10.1007/ s40037-012-0012-5.

Awang, M. M., Ahmad, A. R., Yakub, N. M., \& Seman, A. A. (2016). Historical thinking skills among pre-service teachers in Indonesia and Malaysia. Creative Education, 07(01), 62-76. doi:10.4236/ ce.2016.71007.

Ayupp, K., \& Kong, W. (2010). The impact of task and outcome interdependence and self-efficacy on employees' work motivation: an analysis of the Malaysian retail industry. Asia Pacific Business Review, 16(1-2), 123-142. doi:10.1080/13602380701517048.

Bandura, A. (1994). Self-efficacy. In V. S. Ramachaudran (Ed.). Encyclopedia of human behavior. New York, NY: Academic Press, pp. 1-14.

Bandura, A. (1997). Self efficacy: The exercise of control. New York, NY: WH Freeman and Company.

Cambridge Assessment International Education. (2018). Global education census report 2018. Cambrige: Author. https:// www.cambridgeinternational.org/ Images/514611-global-education-censussurvey-report.pdf.

Chin, S. H., Roslan, S., Kadir, S. A., \& Mahyuddin, R. (2013). Relationship between sources and teachers' sense of efficacy among novice teachers in
Selangor, Malaysia. Pertanika Journal of Social Sciences \& Humanities, 21(2), 579-604. http://www.pertanika.upm.edu. my/.

Corkett, J., Hatt, B., \& Benevides, T. (2016). Student and teacher self-efficacy and the connection to reading and writing. Canadian Journal of Education, 34(1), 65-98. https://journals.sfu.ca/cje/index. $\mathrm{php} / \mathrm{cje}-\mathrm{rce} / \mathrm{article} / \mathrm{view} / 355$.

Dolton, P., Marcenaro, O., De Vries, R., \& She, P.-W. (2018). Global teacher status index 2018. Sussex, England: Varkey Foundation.

Friedman, I. A., \& Kass, E. (2002). Teacher self-efficacy: A classroom-organization conceptualization. Teaching and Teacher Education, 18(6), 675-686. doi:10.1016/ S0742-051X(02)00027-6.

Garvis, S., \& Pendergast, D. (Eds.). (2016). Asia-pacific perspectives on teacher selfefficacy. Roterdam: Sense Publishers. doi:10.1007/978-94-6300-521-0.

Gavora, P. (2010). Slovak pre-service teacher self-efficacy: Theoretical and research considerations. New Educational Review, 21(2), 17-30. http://connection.ebscohost. com/c/articles/70496073/slovak-preservice-teacher-self-efficacy-theoreticalresearch-considerations.

Guo, Y., Connor, C. M., Yang, Y., Roehrig, A. D., \& Morrison, F. J. (2012). The effects of teacher qualification, teacher self-efficacy, and classroom practices on fifth grades' literacy outcomes. The Elementary School Journal, 113(1), 3-24. doi:10.1086/665816.

Jayanti, J., \& Wahyudin, D. (2019). How important are today's teacher development program contents for primary school teacher? Jurnal Penelitian Ilmu Pendidikan, 12(1), 55-62. doi:0.21831/ jpipfip.v12i1.19799.

Klassen, R. M., \& Chiu, M. M. (2011). The occupational commitment and intention to quit of practicing and pre-service teachers: 
Influence of self-efficacy, job stress, and teaching context. Contemporary Educational Psychology, 36(2), 114-129. doi:10.1016/j.cedpsych.2011.01.002.

Klassen, R. M., Tze, V. M. C., Betts, S. M., \& Gordon, K. A. (2011). Teacher efficacy research 1998-2009: signs of progress or unfulfilled promise? Educational Psychology Review, 23(1), 21-43. doi:10.1007/s10648-010-9141-8.

Lih, J. S. J., \& bin Ismail, R. (2019). Binary logistic regression analysis of teacher self-efficacy factors influencing literacy and numeracy. World Journal of Education, 9(1), 209-220. doi:10.5430/ wje.v9n1p209.

McLean, D., Eklund, K., Kilgus, S. P., \& Burns, M. K. (2018). Influence of teacher burnout and self-efficacy on teacherrelated variance in social-emotional and behavioral screening scores. School Psychology Quarterly, 34(5), 503-511. doi:10.1037/spq0000304.

Mehmood, N. (2019). Factors impacting EFL teachers' self-efficacy: A theoritical perspective. English Language Teaching, 12(4), 39-48. doi:10.5539/elt.v12n4p39.

Milner, H. R., \& Hoy, A. W. (2003). A case study of an African American teacher's self-efficacy, stereotype threat, and persistence. Teaching and Teacher Education, 19(2), 263-276. doi:10.1016/ S0742-051X(02)00099-9.

Moma, L. (2014). Peningkatan self-efficacy matematis siswa SMP melalui pembelajaran generatif. [The enhancement of junior high school students' selfefficacy through generative learning]. Cakrawala Pendidikan, 3(3), 434-444. doi:10.21831/cp.v3i3.2387.

Pardimin, P. (2018). Analysis of the Indonesia mathematics teachers' ability in applying authentic assessment. Cakrawala Pendidikan, 37(2), 170-181. doi:10.1016/ S0304-4017(96)01152-1.

Pujaningsih, P. \& Ambarwati, U. (2020). Self efficacy changes in collaborative course for inclusive education preservice teachers. Cakrawala Pendidikan, 39(1), 79-88. doi:10.21831/cp.v39i1.26669.

Rahimah, J., Abu, R., Ismail, H., \& Mat Rashid, A. (2014). Teachers' self-efficacy in teaching family life education. Pertanika Journal of Social Science and Humanities, 22(3), 775-784. http://www.pertanika. upm.edu.my/.

Rido, A., \& Sari, F. M. (2018). Characteristics of classroom interaction of english language characteristics of classroom interaction of english. International Joural of Language Education, 2(April), 40-50. doi:10.26858/ ijole.v2i1.5246.

Selvi, K. (2010). Teachers ' competencies. Cultura: International Journal of PhilosophyofCultureandAxiology, VII(1), 167-176. doi:10.5840/cultura20107133.

Septiana, D. (2018). The influence of emotional intelegence, self-efficacy, and altruism on teacher's competence in inclusion elementary school. Jurnal Prima Edukasia, 6(2), 147-156. doi:10.21831/ jpe.v6i2.14413.

Setiawan, S., \& Dewi, L. (2019). Korelasi kompetensi pedagogik guru dengan pelaksanaan pembelajaran bahasa jawa tingkat smp. Jurnal Penelitian Ilmu Pendidikan, 12(1), 75-88. doi:10.1017/ CBO9781107415324.004.

Seyle, D. C., Widyatmoko, C. S., \& Silver, R. C. (2013). Coping with natural disasters in Yogyakarta, Indonesia: a study of elementary school teachers. School Psychology International, 34(4), 387-404. doi: $10.1177 / 0143034312446889$.

Shaukat, S., \& Iqbal, H. (2012). Teacher self-efficacy as a function of student engagement, instructional strategies and classroom management. Pakistan Journal of Science and Clinical Psychology, 9(3), 82-85.

Skaalvik, E. M., \& Skaalvik, S. (2010). Teacher self-efficacy and teacher burnout: 
A study of relations. Teaching and Teacher Education, 26(4), 1059-1069. doi:10.1016/j.tate.2009.11.001.

Susilana, R., Asra, A., \& Herlina, H. (2014). The contribution of the self-efficacy of curriculum development team and curriculum document quality to the implementation of diversified curriculum in Indonesia. Malaysian Online Journal of Educational Sciences, 2(3), 31-40. http:// www.moj-es.net/.

Tierney, P., \& Farmer, S. M. (2011). Creative self-efficacy development and creative performance over time. Journal of Applied Psychology, 96(2), 277-293. doi:10.1037/ a0020952.

Tschannen-Moran, M., \& Hoy, A. W. (2001).
Teacher efficacy: Capturing an elusive construct. Teaching and Teacher Education, 17(7), 783-805. doi:10.1016/ S0742-051X(01)00036-1.

Tsigilis, N., Grammatikopoulos, V., \& Koustelios, A. (2007). Applicability of the teachers' sense of efficacy scale to educators teaching innovative programs. International Journal of Educational Management, 21(7), 634-642. doi:10.1108/09513540710822229.

Zee, M., \& Koomen, H. M. Y. (2016). Teacher self-efficacy and its effects on classroom processes, student academic adjustment, and teacher well-being: a synthesis of 40 years of research. Review of Educational Research, 86(4), 981-1015. doi:10.3102/0034654315626801. 